\title{
PRECEDE-PROCEED MODEL: PREDISPOSING, REINFORCING, AND ENABLING FACTORS AFFECTING THE SELECTION OF BIRTH ATTENDANT IN BONDOWOSO DISTRICT
}

\author{
Ira Martin Pramiyana1), Uki Retno Budi Hastuti2), Bhisma Murti1 ${ }^{1)}$ \\ 1)Masters Program in Public Health, Sebelas Maret University \\ 2)Department of Obstetrics and Gynecology, Dr. Moewardi Hospital, \\ Surakarta
}

\begin{abstract}
Background: Skilled birth attendant is one of the determinants of maternal and infant mortality. One of the primary causes of maternal mortality in Bondowoso District was the reliance on the traditional birth attendant (TBA). In 2016, the number of birth delivery attended by TBA reached 510 out of 10,326 deliveries. This study aimed to determine the predisposing, reinforcing, and enabling factors affecting the selection of birth attendant in Bondowoso.

Subjects and Method: This was an analytic observational study using case control design. The study was conducted at 5 community health centers in Bondowoso District, East Java, from April to May 2017. A sample of 160 delivering mothers, consisting of 110 mothers assisted by skilled birth attendants and 50 mothers assisted by traditional birth attendants, were selected for this study by fixed disease sampling. The dependent variable was the selection of birth attendant (skilled birth attendant vs. TBA). The independent variables were age, education, working status, ANC visit, tradition, and family support. The data were collected by a set of questionnaire. Path analysis was employed to analyze data.
\end{abstract}

Results: Age 20-34 years $(b=-2.10 ; 95 \% \mathrm{CI}=-3.96$ to $-0.25 ; \mathrm{p}=0.026$ ), working outside the house $(\mathrm{b}=2.23 ; 95 \% \mathrm{CI}=0.84$ to $3.61 ; \mathrm{p}=0.002)$, ANC visit $(\mathrm{b}=2.71 ; 95 \% \mathrm{CI}=0.80$ to $4.62 ; \mathrm{p}=0.005)$, good tradition $(\mathrm{b}=4.05 ; 95 \%$ $\mathrm{CI}=2.38$ to $5.72 ; \mathrm{p}<0.001)$ increased the likelihood of selecting skill birth attendant. Age $20-34$ years $(b=2.54 ; 95 \% \mathrm{CI}=1.24$ to $3.84 ; \mathrm{p}<0.001)$ and maternal education $\geq$ high school $(\mathrm{b}=3.69 ; 95 \% \mathrm{CI}=2.47$ to $4.92 ; \mathrm{p}<0.001)$ increased ANC visit. Maternal education $\geq$ high school $(b=0.74 ; 95 \% \mathrm{CI}=-$ 0.02 to $1.51 ; \mathrm{p}=0.059)$ increased age. Maternal education $\geq$ high school $(\mathrm{b}=$ $1.39 ; 95 \% \mathrm{CI}=0.63$ to $2.14 ; \mathrm{p}<0.001$ ) increased the likelihood of mother working outside the house. Family support $(b=2.02 ; 95 \% \mathrm{CI}=1.21$ to 2.82 ; $\mathrm{p}<0.001)$ increased the likelihood of good tradition.

Conclusion: Age 20-34 years, working outside the house, ANC visit, good tradition, directly increase the likelihood of selecting skill birth attendant.

Keywords: selection of birth attendant, predisposing, enabling, reinforcing factors

Correspondence: Ira Martin Pramiyana. Masters Program in Public Health, Sebelas Maret University, Jl. Ir. Sutami 36 A, Surakarta 57126, Central Java, Indonesia. Email: iramartinpramiyana87@gmail.com.

Mobile: +6282337742697 . 